Chicago-Kent College of Law

Scholarly Commons @ IIT Chicago-Kent College of Law

All Faculty Scholarship

Faculty Scholarship

January 2009

\title{
Competition Law and the Institutional Embeddedness of Economics
}

David J. Gerber

IIT Chicago-Kent College of Law, dgerber@kentlaw.iit.edu

Follow this and additional works at: https://scholarship.kentlaw.iit.edu/fac_schol

Part of the Antitrust and Trade Regulation Commons, Comparative and Foreign Law Commons, and the Law and Economics Commons

\section{Recommended Citation}

David J. Gerber, Competition Law and the Institutional Embeddedness of Economics, (2009).

Available at: https://scholarship.kentlaw.iit.edu/fac_schol/219

This Contribution to Book is brought to you for free and open access by the Faculty Scholarship at Scholarly Commons @ IIT Chicago-Kent College of Law. It has been accepted for inclusion in All Faculty Scholarship by an authorized administrator of Scholarly Commons @ IIT Chicago-Kent College of Law. For more information, please contact jwenger@kentlaw.iit.edu, ebarney@kentlaw.iit.edu. 


\section{Competition law and the institutional embeddedness of economics}

\section{David J Gerber*}

\section{INTRODUCTION}

Transnational debates about the role of economics in competition law have paid relatively little systematic attention to the embeddedness of economics in institutions. They typically proceed as if embeddedness were not an issue. The assumption appears to be that economics looks, acts and functions the same wherever it is applied. This assumption is often the basis for claims supporting increased use of economics in legal systems around the world. The claim is that economics represents a standardized and internationally applicable language and thus that its increased use in competition law will lead to or at least support global harmonization of antitrust law. In particular, European discussions of a 'more economic approach' to competition law often refer to the use of economics in US antitrust law, and they frequently assume that if economics works in a particular way in the United States and has particular consequences there, it will function the same way in Europe and have similar consequences.

Lack of attention to the embeddedness of economics in institutions can be attributed to two sets of closely related factors. One is a lack of sufficient incentives to explore these issues. Economists themselves generally have little reason to study the institutional application of economics. It is not their issue. Their role and function is to talk about the substance of economics itself and to apply its methods. ${ }^{1}$ Legal scholars may be dissuaded from approaching these issues because they do not fit neatly into any exist-

* Distinguished Professor of Law, Chicago-Kent College of Law, Chicago, Illinois.

1 The field known as 'new institutional economics' might be expected to be a locus for this kind of analysis, and there is valuable work in this field that can be used in the type of analysis I engage in here. In this body of scholarship, institutions are important, because they influence economic outcomes. In general, however, institutional economists do not focus on how economics itself is embedded in 
ing category of legal scholarship and, as a result, few intellectual tools have been developed for analysing them. Scholars in the specific field of law and economics might be expected to have some interest in this area, but they have been primarily concerned with importing economics into law at a substantive-law level, and this enterprise provides few incentives to discuss the institutional-embeddedness issues. Finally, practising attorneys may have experience in specific procedural contexts, but seldom have incentives to engage in systematic study of the phenomenon. For each of these groups, the seeming 'messiness' of procedural issues further reduces incentives to study the issues. Institutional embeddedness involves procedural and institutional complexities and irregularities, and it does not easily lend itself to the development of either generalizations regarding methods or predictions about outcomes.

A second set of factors involves institutional and professional interests that may provide disincentives for systematic study of the issues. For example, scholars and lawyers from the United States generally seek to export the US antitrust model. Given that this model is based on a specific role for economics, paying attention to differences between the systems that might interfere with success in exporting the US model might be perceived as counterproductive.

Yet to ignore this institutional factor invites serious distortions in analysing the relationship between economics and competition law. ${ }^{2}$ Institutions condition the use of economics. Their practices and procedures influence not only the norms that are applied, including the appropriate role of economics, but also the factual material that is produced for use by economists and the myriad decisions that are made in reaching outcomes.

My main claim in this chapter is that we need to analyse institutional embeddedness if we wish to evaluate and analyse the role of economics in legal institutions, in general, and in antitrust law, in particular. The underlying issues in virtually all legal analysis are 'what decisions will be made?' and 'what kinds of factors influence those decisions?' Given the extraordinary increases in the value of economics in some areas of the law, it is critical to identify and assess the modalities through which economics influences decisions, and here the institutional-embeddedness issue is of central importance.

institutions. For discussion of recent developments in the field, eg JN Drobak and JVC Nye (eds), The Frontiers of the New Institutional Economics (1997).

2 I use the term 'competition law' here to refer to general legal regimes that impose sanctions on conduct because such conduct restrains competition. The term 'antitrust' is often also applied to this type of legal regime, particularly in reference to the competition law of the United States. 
The need for this type of analysis is particularly striking where claims are made that extend beyond the borders of a single legal system. Any claim or assumption that experience with economics in one system is relevant to decisions in another system is suspect if it does not take institutional embeddedness into account. In these contexts, economics is applied by different institutions and subject to different institutional and procedural influences. The respective institutional contexts will each shape decisions in their own ways, and these will often lead to very different roles for economics and economists and thus potentially very different outcomes.

To illustrate these issues, I here examine them in an arena in which they are of particular importance. Europe is moving toward greater use of economics in competition law, and in this context there are frequent references to US antitrust experience with economics. There are claims, for example, that increased use of economics in European competition law will lead to greater convergence in competition law between the US and Europe and thus more uniform rules to guide transatlantic business. Such claims are of little value and may even be harmful unless they are based on appropriate analysis of institutional-embeddedness factors.

This chapter examines the issue of institutional embeddedness and some of the ways in which it is important. ${ }^{3} \mathrm{I}$ apply the analysis to the European discussion of a 'more economic approach', examining some of the procedural and institutional differences that deserve to be considered where the role of economics in US antitrust law is viewed as relevant to the use of a 'more economic approach' in Europe. Failure to appreciate the institutional and organizational embeddedness of economics in US antitrust law and to recognize differences between US and European decisional contexts can distort assessments of US experience and may reduce the potential value of references to it. It may lead to inappropriate and unfounded expectations and thus to ill-advised decisions. Sharper awareness and clearer analysis of these differences may, however, increase the potential value of references to US experience and lead to a clearer vision in Europe of some of the implications of increasing the role of economics in competition law.

I have four main objectives. One is to examine the embeddedness of economics in US antitrust law. Revealing the factors that condition the use of economics in institutions makes clear the value of taking them into account in analysing the role of economics in competition law. A second is to compare the factors that influence how economics operates in US antitrust

${ }^{3}$ Although in this chapter I limit the discussion to the competition-law context, I believe that the analytical principles can also be applied with value to other areas of law in which economics is used. 
law and the way it operates and could operate in Europe. A third aim is to identify some of the implications of this type of analysis for decisions that are now being made in Europe and those that will have to be made in the future. The fourth is to offer a method of analysing the embeddedness issue that can be of value not only in the context of individual legal systems, but in any situation in which references or claims are made about the role of economics that transcend the boundaries of a single system.

\section{ECONOMICS AS SCIENCE: THE UNIVERSALITY POSTURE}

A starting point for thinking about the institutional embeddedness of economics is its universalist posture. Universality is at the core of the scientific enterprise, and thus as a social science, economics seeks universally valid principles. The language of economics is, therefore, necessarily abstract, and its methods are intended to be applicable everywhere. ${ }^{4}$ In general, economists assume that economics is the same here, there and everywhere, regardless of cultural or other contexts. ${ }^{5}$ The 'internationalization' of economics over the last half century is largely based on this postulate, as is much of the extraordinary development of economics as a science. ${ }^{6}$

This does not mean, of course, that economists are unaware of such contexts, but rather that they view their analytical tools as independent of context. Most economists recognize that cultural and institutional factors may influence not only legal and political decisions involving economic issues, but also economic processes themselves. Nevertheless, these issues are not generally considered part of the discourse of economics itself. They are relegated to a separate realm referred to as the practical application of economics. In this realm, economics can be, and often is, applied by noneconomists. ${ }^{7}$

This universalist perspective is fostered by the orthodoxy of a particular set of goals and methods within the economics profession. Among the most important of these are the assumptions that economic actors

4 For general discussions of economics methodology, eg $\mathrm{M}$ Blaug, The Methodology of Economics: Or How Economists Explain (2nd edn, 1992) and LA Boland, The Methodology of Economic Model Building (1999).

5 For discussion, see MW Reder, Economics: The Culture of a Controversial Science (1999).

6 This development is described and analysed by AW Coats, The Post-1945 Internationalization of Economics (1997).

7 For analysis of the use of economics in government, see eg AW Coats, Econonists in Government: An International Comparative Study (1981). 
generally act 'rationally', at least in most spheres of activity, ${ }^{8}$ that efficiency assessments are at the core of economic analysis and that mathematics must play the central role in the development of economic theory. These core values and postulates have developed as a result of a specific set of concerns and objectives, and the culture of the economics profession now replicates and reinforces them. ${ }^{9}$

From the standpoint of economic analysis, there is great value in this universalist posture. It fosters analytical precision, permits the broad applicability of analytical work, and, above all, releases the power of abstraction in the formulation of economic principles. These are primary considerations within the economics community, and they have proven their value in developing both theory and policy. In addition, they provide status to practitioners of the science, which in turn contributes to both the social and market value of the roles that economists play.

\section{INSTITUTIONAL EMBEDDEDNESS: SOME USES OF ECONOMICS IN COMPETITION LAW}

This universalist posture tends, however, also to conceal and to be confused with a different set of issues that involves the use of economics in institutions. Institutions use economics for specific purposes. Here the universality posture is misplaced and may be misleading. The scientific claims, universal methods and abstract language-the factors whose very universality makes the scientific enterprise of economists valuable-now become embedded within institutional contexts in which they cannot operate as they operate within the scientific community of economists.

In these contexts, the methods of economics become tools to be applied according to the rules and procedures of the institutions and organizations that use them. Where economics is used in institutions, the categories, methods and language of economics share decisional space with other factors. Specific institutional and procedural contexts shape the ways in which economics is used and the outcomes reached by those using it. It cannot operate at its accustomed level of discursive universality, but must now contest with other specifically institutional factors in influencing legal decisions and outcomes.

\footnotetext{
8 This rationality assumption has been subject to increasing limitations among some groups of economists, especially in recent years. In the context of the use of economics in competition law, it remains little challenged. For discussion of the most recent movements of this kind within the economics profession, see D Coyle, The Soulful Science: What Economists Do and Why it Matters (2007).

9 For discussion of that cultural function, see eg Reder, supra note 5.
} 
When used in the specific context of competition law, economics plays two main roles, each of which is shaped by specific institutional and procedural factors. ${ }^{10}$ One is normative. In it, economics supplies the content of legal norms. It provides the normative standards that are applied to conduct in order to assess whether the conduct is deemed to violate law. In doing this, it shapes the questions to be asked in competition law, supplying the concepts and categories that are used in the process of assessing the lawfulness of conduct. Concepts and categories drawn from economic science - such as, for example, 'efficiency' - become operative standards of the legal system. This requires some mechanism for relating the economics concepts and language to those of the legal system. In effect, it requires that economics be grafted onto the authoritative legal-political basis for decisions in the competition-law system.

The other role is that of fact interpretation. Here the role of economics is to specify methods to be used in answering factual questions - questions about what has happened or what the consequences of particular conduct are likely to be. Given that antitrust law is designed to prevent particular kinds of harm to the competition process, the issue is often 'Did particular kinds of conduct 'cause" particular results?' This may involve issues such as the assessment of the market power of the enterprises involved, the characteristics of the markets in which they operate and other purely factual issues. Economic science can provide abstract models and testable hypotheses for use in making these factual determinations, and it can supply methods (eg econometrics) for analysing them.

\section{TRANSNATIONAL COMPETITION LAW ISSUES AND ECONOMIC EMBEDDEDNESS}

With this distinction in mind, we can see that any cross-system reference involving the role of economics requires careful analysis of the embeddedness issues. Each competition system conditions these two roles of economics in specific ways. With regard to the normative role, for example, it will use different institutional means to relate the substantive principles of economics to legal norm-setting processes of the competition-law system. Depending on the legal system, this may require specific authority located in a statute or it may be within the authority of courts to establish and define the relationship. On this issue, there are major differences between

10 I develop this distinction more fully in DJ Gerber, 'The Future of Article 82: Dissecting the Conflict' in C-D Ehlermann (ed), European Competition Law Annual 2007: A Reformed Approach to Article 82 EC (forthcoming). 
the US antitrust system and European systems: US courts typically have far greater authority to shape this relationship than do analogous European courts. ${ }^{11}$

The second or fact-interpretation function is also performed in systemspecific ways. Specific institutional arrangements in the competition-law system will, for example, provide the means for acquiring data, specify the kinds of data that can be acquired, identify the agents that are permitted to acquire the data, designate the potential sources of data, assign spheres of control of the data and so on.

Of the many elements of US litigation that are relevant to the embeddedness of economics, I have chosen three for closer examination here. One involves the amount of data that is available for evaluation by participants in the fact-interpretation process. This includes the procedures for access to information. A main value of economics in competition law is its capacity to evaluate data, and the amount of data available and access to data are central to making use of its potential value. A second involves control over data. Who can get, use and control data, under what circumstances and subject to what kinds of constraints? The third relates to the interpretation of data. Economics 'interprets' data, and thus the institutional mechanisms for performing that function are keys to the outcomes that are reached.

These three components of the US system condition the use of economics in fundamental ways. They determine how much data is available and thus the degree of empirical testing of abstract propositions that is possible. They determine how the presentation of data is organized and controlled, thereby determining the roles of economists and the relationship between those roles and the roles of lawyers and judges. And, finally, they determine the factors that will influence the process of interpreting the data, the process on which much of the value of economics rests.

One criterion for selecting these three factors is the centrality of their roles in both the operation of the system generally and in relation to the embeddedness of economics. Another is my experience that they are often overlooked or misunderstood by outside observers. I look first at the amount of information available for economic analysis, then at control over information and, finally, at the interpretation of the data that is available.

11 For comparative analysis of these types of differences, see DJ Gerber, 'Competition Law' in P Cane and M Tushnet (eds), Oxford Handbook of Legal Studies (2004) 510, and DJ Gerber, 'Comparative Antitrust Law' in M Reimann and R Zimmermann (eds), Oxford Handbook of Comparative Law (2007) 1193. 


\section{USING US ANTITRUST EXPERIENCE IN THE EUROPEAN CONTEXT}

We can now apply this analysis to the specific example of the use by Europeans of US antitrust experience. As noted, the European Commission's efforts to use a 'more economic approach' have been much influenced by US experience, and thus it is valuable to analyse the intellectual basis for references to that experience and the kinds of issues that need to be explored in making such references effective.

In the late 1990s, the European Commission began to change fundamental components of its competition law. Since then, European competition law has moved toward what is generally described as a 'more economic approach'. ${ }^{12}$ The term is used loosely to refer to increased use of economics in competition law and includes increased reliance on economic science to inform the norms of competition law. Economics increasingly is given the role not only of improving the interpretation of data in competition-law cases, but also of supplying its norms and methods. ${ }^{13}$ With the introduction in 2004 of the requirement that European Union competition law be applied by Member States in virtually all competition cases, this movement toward increased reliance on economics has expanded in scope and become relevant to the application of competition law throughout Europe. Many questions remain as to how economics will actually be used, especially by Member State competition authorities and courts, and thus the role of economics is likely to remain a topic of central concern for many years.

US experience has played an important role in this development. The role of economics in competition law that is espoused by the European Commission is essentially the same as the role that economics now plays in US antitrust law. This conception of the role of economics is the basis for the substantive law changes that the European Commission has introduced into the assessment of vertical and horizontal agreements as well as mergers and that it is currently proposing for use in the context of unilateral conduct (Article 82 of the EC Treaty).${ }^{14}$ In this process of change, US

12 For discussion of the more economic approach, eg LH Roeller, 'Economic Analysis and Competition Policy Enforcement in Europe' in PAG Bergeijk and E Klosterhuis (eds), Modeling European Mergers: Theory; Competition Policy and Case Studies (2005) 11.

13 For analysis of some of the controversies concerning the use of economics in European competition law, with particular reference to distinguishing among the various uses of economics in applying Article 82, see Gerber, supra note 10.

14 The Commission's recent thinking about the future of Article 82 can be found in 'CDG Competition Discussion Paper of application of Article 82 of the 
experience has frequently been used to support and justify the move toward increased use of economics, often under the rubric: If the US does it, and it seems to be associated with positive economic developments there, perhaps we should do it as well. In that sense and others, US antitrust law experience has been a major reference point in Europe's 'more economic approach' movement.

These references in Europe to US experience seldom pay significant attention, however, to embeddedness issues, in particular, differences in the institutional and procedural contexts that condition the operation of economics in these two decision-making contexts. References to US experience typically proceed as if either there were no significant differences between the two decisional contexts or such differences were irrelevant to assessing the use of a 'more economic approach' in Europe. As we shall see, however, there are major differences in the institutional and procedural contexts of the use of economics between the US and Europe, and these need to be taken into account in relating one to the other.

\subsection{The Role of the Federal Courts}

In order to pursue this analysis, we need to limit its scope and compare similar institutions performing analogous roles. Several institutions are instrumental in the US antitrust system, but by far the most important are the federal courts, and thus this article focuses on the roles played by those courts. It examines how economics is embedded in their decisional processes and assesses the importance of that embeddedness for the use of US antitrust experience in Europe. ${ }^{15}$

I have chosen this example because of its importance, but also because foreign observers often misunderstand it. Litigation in the federal courts is the central institutional context for the creation and application of US antitrust law and thus for the use of economics in the US antitrust system. For most purposes, it is here that antitrust law is made. Decisions of the federal courts are the authoritative pronouncements that officially guide decision making in antitrust law. They are particularly important in this area of law, because other forms of authority and guidance play limited

Treaty to exclusionary practices', December 2005, http://ec.europa.eu/comm/competition/antitrust/art82/discpaper 2005.pdf (accessed 31 January 2008).

15 For discussion of the role of litigation in the US antitrust system from a comparative perspective that relates US experience to the situation in Europe, see DJ Gerber, 'Private Antitrust Enforcement in the U.S. and Europe: A Comparative Perspective' in TMJ Moellers and A Heinemann (eds), The Enforcement of Competition Law in Europe (2008) 431. 
roles. Legislation plays virtually no role in the area. The basic antitrust statute was enacted in 1890, and the last major legislative change occurred almost a century ago. ${ }^{16}$ Moreover, administrative decision making is also far less influential in the US system than it is in most other competition-law systems.

Because federal courts play a role in the development and operation of the US antitrust system that is more central than that played by courts in most competition-law systems, foreign observers often underestimate the centrality of that role. In most systems, courts either play no direct role or merely review administrative decisions for procedural or constitutional flaws. Courts there may engage in varying degrees of review of administrative action, but typically their role is relatively limited. In the US, however, the federal courts do far more. They are the centres of the system - the principal arbiters of what the law is and the primary factors in developing the law. Court decisions and case-law interactions among courts are the reference point for both public enforcers and private lawyers in making competition-law decisions. In most other competition-law systems, the administrative authority responsible for competition law plays a far more central role in the system than it does in the United States.

The federal courts are central to both public and private enforcement of the antitrust laws. In the US system, two agencies of the federal government are authorized to enforce the competition laws. One is the Antitrust Division of the United States Justice Department, which is part of the executive branch of government. It has often been considered the more influential of the two agencies. Yet the Department of Justice generally cannot enforce the antitrust laws directly! When it wishes to take action, it must generally do so by commencing litigation in the regular jurisdiction federal courts. It must win its lawsuit there in order to effectuate its enforcement decisions and achieve its enforcement goals. Moreover, when the Justice Department goes to court, it is generally subject to the normal procedural rules of the federal courts. The Justice Department may choose to bring a civil suit or a criminal suit, depending on the claims involved, and the corresponding procedural rules are applied to the litigation. With limited exceptions, there is no separate procedure specifically designed for antitrust litigation. I emphasize these points because foreign observers are often 'shocked' by the fact that the US Justice Department must actually go to the regular courts in order to take enforcement action and by the further fact that when it does go to court, it is typically subject to the

16 Some might also consider the 1950 expansion of the scope of application of the merger control provisions to be a major legislative change. 
ordinary procedural rules of those courts. The other enforcement agency is the Federal Trade Commission. It operates as an independent agency, and it may issue orders directly. Nevertheless, its actions are subject to both procedural and substantive review by the federal courts, which impose the same substantive antitrust rules to decisions by the FTC as they apply to all other antitrust litigation.

The centrality of the federal courts in the US system is further enhanced by the importance of private antitrust litigation. This form of litigation takes place in the same federal courts that control public enforcement. Private antitrust litigation is common, providing most of the decided cases in the area, and it is often viewed as at least as important as public enforcement in implementing the antitrust laws, if not more important.

\subsection{Some Key Procedural Features of Antitrust Litigation in US Federal Courts}

As background, it is important to note several basic features of litigation in the US that are relevant to the issues treated here. ${ }^{17}$ The common-law model of litigation that evolved in England and that operates in modified form in the US relies on a set of roles for judges in first-instance (ie trial) litigation that is quite different from the roles usually played by judges in continental Europe. In it, the judge is primarily a referee or umpire whose role is to enforce the rules of procedure and ensure fair proceedings within those rules. She has no obligation to know all the substantive law that might be applicable in a case before her, and she does not develop the case herself. The system relies on the attorneys for each side to develop their own cases and to present fully developed legal and factual arguments to the respective decision makers (judge or, as the case may be, jury), who must choose among the elements presented. The judge's primary role during firstinstance litigation is to monitor this interplay between the attorneys.

A second key feature of this litigation model is the basic principle that competition or conflict between the attorneys is likely to produce the best outcome. In order to achieve this result, the procedural mechanism provides extensive power and responsibility to the lawyers for each side. The image is that the attorneys are empowered to make their best cases; the procedure identifies the conflicts between the two sides; and a neutral and impartial jury or judge makes the factual determinations based on the

17 For an analytical framework for comparing procedural systems that treats many of these issues, see DJ Gerber, 'Comparing Procedural Systems: Toward an Analytical Framework' in JAR Nafziger and SC Symeonides (eds), Law and Justice in a Multistate World: Essays in Honor of Arthur T. Von Mehren (2002) 665. 
material and arguments presented. ${ }^{18}$ The procedure does not centre on the judge's knowledge of the law or assign to the judge responsibility for developing either legal or factual arguments.

US federal procedure has added another important component to this model that plays a key role in the issues here - the centrality of factual density to the litigation process. ${ }^{19}$ At one level, this factual density is captured by the common claim among US lawyers and judges that 'facts win cases' - that is, that the central issues in litigation are generally factual issues and that whoever has the most and best evidence is likely to win. It also reflects, however, a concept of procedural justice that often goes unnoticed. This basic conception is that maximum access to factual data produces the best and fairest results.

Both ideas reflect an underlying view of the litigation process in which the substantive law appears as flexible and somewhat indeterminate and in which, therefore, factual detail and the sensitivity of the procedure to the specifics of the case are key means of legitimating the process. This means that the foremost objective of lawyers is often to present a convincing factual presentation and to master the factual contours of the case. The importance of this function is further enhanced by the heavy reliance on factual comparisons in a case-based system. Similarities and dissimilarities between the facts of a case being decided and the facts of prior authoritative cases (precedents) are central to legal decision making. Effective comparison of factual scenarios is a key to successful litigation strategies.

Given the importance of this factual analysis, access to data is seen as key to producing the best outcomes for the parties and legitimating the system itself. This, in turn, supports the proposition that the procedural mechanism should provide extensive rights for the lawyers to acquire information. In no area of US law is this more important than antitrust law, because, as noted above, virtually all antitrust law is made by the courts.

Three additional factors are important for assessing the role of courts in antitrust cases and understanding the embeddedness of economics in US antitrust law. First, the US antitrust system assumes that private litigation is of primary importance in securing compliance with antitrust law. In fact,

18 In US civil litigation, a defendant is generally guaranteed a right to jury trial by the US Constitution. If a jury is present, it resolves all issues of fact, leaving the legal issues to be dealt with by the judge. If no jury is present, the judge resolves issues of fact as well as law. Basically, the same evidentiary and procedural rules are followed in both cases.

19 For discussion of procedural-justice issues in US and European litigation, see DJ Gerber, 'Extraterritorial Discovery and the Conflict of Procedural Systems: Germany and the United States' (1986) 34 Am J Comp L 745. 
most antitrust litigation in the US is private litigation, and many of the most important cases are private cases. Private litigation is thus at the centre of the system. Second, several procedural provisions are intended specifically to encourage private litigation. For example, successful private plaintiffs are awarded compensation in an amount equal to three times the actual damage sustained (so-called treble damages). This provision is specifically intended to encourage private litigation. Third, antitrust litigation can take several forms - private, administrative and criminal, and, as noted, the procedural rules vary according to the form of the litigation. Private litigation follows the basic rule of civil procedure, while Department of Justice litigation may follow civil litigation rules or criminal procedure rules, depending on the type of conduct involved, and Federal Trade Commission litigation generally follows administrative procedural rules.

\subsection{The Comparative Reference Point: Analogous European Institutions}

In relating this role of economics in US antitrust litigation to the European context, a key issue is finding an appropriate reference institution - what exactly is to be compared? As noted, European competition law relies far more heavily on administrative decision making in applying and enforcing its norms than does US antitrust law. This, by itself, represents a major dissimilarity between the two systems and raises fundamental questions about the use of US experience in the European context, but comparative issues of that magnitude are beyond the scope of this chapter. Instead, the chapter compares courts with courts. This permits an analysis of specific issues of competition-law decision making in the judicial context itself and avoids the fundamental differences between court procedures and administrative procedures. ${ }^{20}$ This will enable us to identify differences in the ways in which analogous European institutions condition the use of economics.

It also compares European national courts with US courts, thereby leaving aside the special institutional roles of the two European Union courts. Moreover, the comparison focuses on the first-instance competition law courts in which litigation typically takes place. This is necessary in order to ensure that the comparison relates institutions performing analogous functions. While it is true that national courts have so far played a relatively minor role in the European competition-law context, our concern here is with identifying aspects of the institutional embeddedness of economics, and from this perspective the current amount of private litigation in Europe

20 These comparisons are also relevant in many respects to many administrative proceedings, not only in Europe, but also in many other systems that have been influenced by European models. 
is not at issue. Nevertheless, there is also significant practical importance in the comparison, because private litigation in competition law has been increasing in Europe, and because the European Commission is currently advocating a major increase in reliance on such litigation in Europe. ${ }^{21}$ The issue is thus of particular importance for the future development of European competition law. 22

Comparing the decision-making contexts of US courts with those of European courts at this level of generality requires identifying features that are common to continental European procedural systems. There are, of course, significant differences among procedural systems in courts on the European continent, especially between those with predominantly Germanic influence (eg Austria and Sweden) and those with predominantly French influence (Italy and Spain are examples). Nevertheless, we can identify patterns that generally appear in continental procedural systems, and we will here focus on those widely shared features. This chapter does not refer to the common-law-based procedural systems of the United Kingdom and Ireland, because their deviations from the continental pattern are too extensive to be tractable in the space available.

Finally, even in a specific national court system there are sometimes significant procedural differences among the types of courts that may be involved in antitrust litigation. For example, there may be differences in procedure between general-jurisdiction courts and administrative courts. This chapter does not address such differences directly, but many of the features of procedure used in this analysis are often applicable to other courts, because they rest on many of the same principles of procedural justice. In any event, the purpose here is to identify differences rather than to engage in detailed description of specific courts.

\subsection{Continental Civil Procedure: Some Basic Principles}

The starting point for any such comparison is to recognize that courts in continental Europe generally operate according to a principle of centralization of procedural authority and responsibility that contrasts sharply with the principle of dispersion of procedural responsibility that we have

21 European Commission, Green Paper - Damages actions for breach of the EC antitrust rules, 19 December 2005, COM(2005) 672 final $=$ http://eur-lex. europa.eu/LexUriServ/LexUriServ.do?uri f"MathematicalPi 1">5COM:2005: 0672:FIN:EN:PDF (accessed 31 January 2008).

22 Although the Commissions modernization plans call for increased reliance on private enforcement, many in Europe do not share this objective. For discussion, see W Wils, 'Should Private Antitrust Enforcement be Encouraged in Europe?' (2003) 26 World Conp 473. 
identified in US procedure. The basic image is that the court represents 'the state' and that it is the responsibility of the state's employees - that is, the judges - to control the proceedings. ${ }^{23}$ This means that typically a judge will have the full responsibility for developing the litigation and controlling the procedure. She will, for example, decide whether there is enough evidence for litigation to commence and then develop a file (or 'dossier') that represents the official record of the proceeding. She determines herself issues such as what data is to be presented to the court, which witnesses, if any, may be heard by the court and which questions, if any, may be posed to witnesses. ${ }^{24}$ She thus determines the scope and shape of the factual material. The file is all important. It contains, in essence, the litigation data, such as, for example, the judge's determinations on points of fact and law and her notes on witnesses and the like. In this procedural context, the role of lawyers tends to be far more limited than in the United States. For example, they typically do not call their own witnesses, cross-examine witnesses, prepare witnesses, hire their own experts, control what witnesses say and so on.

This model rests on a specific conception of judicial professionalism. ${ }^{25}$ While US federal judges are often appointed to the bench after many years of experience in practice (or, occasionally, in law teaching) the continental judge is typically a lifetime career civil servant who is trained specifically for the judicial role immediately after university training and who generally remains a judge throughout her career. The judge is required to know the substantive law applicable in the cases she handles and to apply it fairly to the disputes before her. Her professionalism and her knowledge of the substantive law are central legitimating features of the system.

Key elements of the US system are simply not present in these systems or play marginal roles. I mention only two. First, whereas the central concept of US procedure is that justice is best served by a procedure in which competition and conflict between the parties to the litigation are encouraged and the parties are given maximum opportunity to develop and present their own cases, the central idea of continental procedural systems is that the professional judge's knowledge and control of the proceedings is the primary source of procedural justice. ${ }^{26}$ Second, the idea fundamental

\footnotetext{
23 For analysis, see M Damaska, The Faces of Justice and State Authority (1986).

24 In these courts, witnesses normally provide their material in 'raw form' - ie as a single, connected narrative rather than in response to questions from lawyers or from judges. In some systems, especially those of the French procedural tradition, 'live' witness testimony plays a minor role in most litigation.

25 For discussion, see Gerber, supra note 19, at 767-9.

26 For useful analysis of the issues, see JH Langbein, 'The German Advantage in Civil Procedure' (1985) 52 U Chi L Rev 823. Some of the factual references in the article are no longer accurate, but the analysis remains valuable.
} 
to US procedure that access to factual material is the key to effective justice has at best minimal resonance in continental systems.

\section{DATA ACCESS AND THE QUANTITY OF INFORMATION}

The amount of data available for analysis by economists is a key factor affecting the role and operation of economics in a competition-law system. Where economists have large amounts of data and a high degree of access to data that they wish to obtain, their roles and value are significantly enhanced. The importance of these data-access issues has tended to increase in both the US and Europe over the last two decades, as per-se rules have been discarded or tempered in order to allow courts to look more carefully at specific factual circumstances in assessing harm to competition.

\subsection{US Procedure: The Abundance of Data}

A central aspect of procedure in US federal courts is the extensive capacity it provides to litigants to acquire data. The so-called 'discovery' process is of immense importance to the entire embeddedness issue. ${ }^{27}$ This mechanism provides litigants with broad rights to request and, in practice, virtually to compel the presentation (so-called production) of information from other parties and sometimes even from others who are not parties to the litigation. These rules require a litigant, on request by another litigant, to make available to her all information requested by her that can reasonably be expected to lead to evidence that is 'admissible' (ie that can be presented in court). This includes allowing requesting attorneys to examine large numbers of documents and depose (ie formally interrogate) those who may have relevant information.

The form and extensiveness of these rights to demand information require emphasis, because they represent a process that is distinctive for US procedure. A key to understanding the importance of this feature is recognizing the standard used in assessing the 'relevance' of information sought. This standard is often misunderstood by foreign observers. ${ }^{28}$ It is far broader than relevance standards in most litigation systems in

27 For discussion of US discovery practices from a comparative perspective, see DJ Gerber, 'International Discovery after Aerospatiale: The Quest for an Analytical Framework' (1988) 82 Am J Int'l L 521.

28 For further discussion, see Gerber, supra note 19, at 761-7. 
that it encompasses information that may simply be expected to lead to admissible evidence. It is not limited, as in most systems, to data that is directly probative of claims in the litigation. This often enables litigants to acquire very large amounts of information, some of which may be sought for strategic business reasons unrelated to the litigation.

The discovery mechanism can, and often does, yield massive amounts of information that then become part of the litigation process. Many rooms filled with physical documents (or their digital representations) are not uncommon in large litigation. Teams of many lawyers and legal assistants may spend years investigating, sorting and evaluating documents. While there are some judicial controls on the extent of discovery, as noted below, the main constraints are often those of cost. Note also that throughout this process the lawyers for the parties are often in contact, coordinating aspects of the discovery process, negotiating over the extent of discovery and often arguing about matters such as the propriety of particular requests for information. This interaction typically proceeds with little or no judicial supervision.

Several additional features of this 'discovery' process are important for purposes of comparison. First, the process occurs before the first-instance procedure (ie the trial) begins. This means that it is carried out by the attorneys in developing their own respective presentations of the data and before there has been any evaluation by a judicial official of the legal claims to which the data relates. Second, the discovery process is typically not closely supervised by a judge. Judicial supervision is normally only available with respect to specific issues involving the scope of a request, and it must typically be requested by one of the parties. Again, the contrast to continental European litigation systems is stark..$^{29}$

This aspect of US civil procedure has profound implications for the use of economics in the context of antitrust litigation. First, and above all, it means that there is an open and relatively unencumbered field of operation for economic analysis. There is an abundance of data to be examined and explored. Moreover, economists and lawyers are basically in charge of the process of gathering the data. They can ask for and usually obtain data that they think might be relevant to the cases that they are constructing. As we shall see, European procedural systems do not provide this freedom of operation for economists and their methods.

29 A practice called 'managerial judging' is found in the federal courts, and it does involve some supervision of the discovery process. It does not, however, fundamentally change the basic situation created by discovery. First, it is not used in all cases, usually only in larger cases. Second, it involves nowhere near the kind of control of the procedure that is found in continental procedure. 
Second, it provides extensive opportunities for testing theories. The claims of economists can be based on a far broader data set than can be created under continental procedures. In essence, where lawyers and economists seek to evaluate an economic claim, they have procedural tools available that aid them in identifying data that might be relevant to supporting that claim and additional tools for actually acquiring it. Economists can then use this data to test the claim and, presumably, to achieve more reliable and effective analysis of the data. The extensiveness of the data available to economists can thus significantly enhance the weight and probative value of the work of economists and generally support their role.

The availability of data and the capacity to acquire such extensive data also generate incentives for testing economic claims. Where the capacity to acquire such data exists, the lawyer/economist team for each party has an incentive to acquire and analyse it. Moreover, each litigation team has strong incentives to gather and analyse during the discovery process all data that might later be considered relevant at the trial stage of the proceedings, because it must seek to avoid encountering claims made at the trial by the other party that relate to factual data that it has not evaluated. Once the trial has commenced, it is generally too late to seek such data.

\subsection{Europe: Bring your Own}

Data access in continental civil procedure is far more limited than in US federal courts, and US-style discovery has no close analogues in continental procedure. The state is not considered responsible for providing a mechanism by which litigants can coerce the presentation of data from other litigants or from third parties. Moreover, the court itself usually has limited authority to demand such information. A judge can typically do so only under highly restricted conditions such as, for example, where a party provides evidence that such data is likely to be directly relevant to a specific claim (ie directly probative of an essential element of the claim). In general, therefore, the lawyers for the parties have little or no access to data from other parties or from third persons. In addition, the only data typically available to the judge is that which can be found in the public record, data that the parties themselves voluntarily bring to the case, and some limited and specific forms of data that the judge is authorized to require a party to submit to the court (eg a document to which a witness has referred in the proceedings). Moreover, even in situations where a judge has authority to require the presentation of data, she has little incentive to do so, because she may not have the resources in time or personnel support necessary to 
process or analyse it. In addition, the costs must typically be borne directly by her employer, the state. This represents a significant impediment to the gathering of extensive data and again contrasts with the situation in the US, where the incentives are aligned to encourage the development of such data.

So-called piggy-backing procedures are available under the competition laws of some continental countries. Here private litigation follows administrative enforcement and can make use of at least some of the factual material presented in the administrative procedure. These procedures do increase the availability of data, but even here the data access is relatively limited compared with US procedures.

The litigation thus proceeds with access to far less data than is available in the United States litigation system, and, as a consequence, there is less data available for economic analysis. This has three main consequences for the use of economics. First, it means that the value of economics is reduced because there is less opportunity to use it. There is limited material to which economic analysis can be applied. Second, the material that is available tends to be 'thin', potentially reducing the value of certain forms of economic analysis. For example, there may not be sufficient data to adequately support particular kinds of econometric analysis. Third, it means that economic theories cannot be tested to the same degree as they can be tested in the US. One important use of economics is to provide theory-based hypotheses and models that can inform the analysis of factual data. Where the data is insufficient to test these models, their value is limited. ${ }^{30}$ In general, much of the value of economics in antitrust litigation is its utility in analysing complex factual situations. In the European context, the limited amount of data reduces that value.

\section{DATA CONTROL}

A second key issue relating to the institutional embeddedness of economics involves control over data. The procedural system conditions the role of economics by determining the extent to which lawyers and economists can control components of the data set. This includes issues such as whether the data can be used by economists without restrictions, whether there are obligations to make acquired data available to opponents prior to litigation and how data can be presented to those who make decisions regarding the 'facts' of the case.

30 For further discussion of economic modeling issues, see Boland, supra note 4. 


\subsection{US Antitrust: Control by Lawyers}

In the US federal courts, data is controlled to a very significant extent by the lawyers for the parties. Lawyers for each side not only acquire their own data, but also have basic control over the presentation of data to judges or, as the case may be, juries. The discovery process is in their hands, subject, as mentioned above, to controls to prevent abuse. They decide, for example, which witnesses will be heard in court, and they ask the questions to which the witnesses must respond and beyond which their answers may not go. The questions of the lawyers thus structure the data presented to those who decide factual issues. In addition, the lawyers may prepare their own witnesses, and they often discuss in detail with their witnesses what the latter will say, what questions will be presented and so on. The lawyers also crossexamine the witnesses of their litigation opponents. In short, the presentation of data by the lawyers structures the discussion and analysis of the data that is then subsequently presented to the official decision makers (ie judge or jury). This treatment of witnesses also applies to expert witnesses, who are hired by each side and who form part of the respective litigation 'teams'.

This data control by the lawyers has at least three significant consequences for the use of economics in antitrust. First, it allows economists (working with lawyers) to develop economic analysis according to their own needs and objectives, subject only to reasonableness requirements and the cost constraints imposed by their clients. They can use the discovery process to seek information relevant to economic theories that are being considered, and subject the resulting data to econometric or other forms of economic analysis - all generally without interference from the court.

Second, and related, it means that economists can direct their dataanalysis efforts specifically to the legal arguments of their respective teams. They are not expected to be neutral arbiters, as are the judge and the expert witness in continental procedure, but to give the interpretation that best favours their clients' position. Their incentives are, therefore, to explore new theories and to 'push' the theoretical and factual basis for their claims as far as possible.

Third, the process creates opportunities for contesting economic claims and arguments. As the economists work during the proceedings, their claims are often used by the lawyers in negotiations with opposing lawyers. For example, if one line of investigation seems particularly strong, it may strengthen the negotiating position of the lawyer in settlement negotiations. In this process, however, each side often has opportunities and incentives to challenge the other side's economic and factual analysis. Ideally, this process reveals the strengths and weakness of the economic analysis and leads to more accurate and valuable factual analysis. 


\subsection{Europe: Control by the Judge}

In continental European courts, the control of data has rather different characteristics. As noted above, continental civil procedure generally features the judge as the director of the entire litigation process, controlling the development of the case and, in particular, the acquisition and presentation of data. Unlike the situation in the US, the lawyers do not shape and define the presentation of data to the decision maker. The judge builds a file that contains the data and/or descriptions of it by the judge. She also determines and generally controls the process of data collection. Lawyers may not present the factual case as they wish and subject to their own control, as is the case in the US. There is also no broad cross-examination mechanism (and sometimes no cross-examination at all) that allows lawyers (and economists) to challenge the presentations made by the other party (and her economists). Finally, experts are designated and called by the court in most cases, and they are responsible only to the court. They are not presented by each of the parties as is the case in the US.

Timing factors in the relationship between legal assessment and factual presentation also differ dramatically from the situation in the US. In Europe, the judge typically begins to assess both factual and legal claims at the commencement of the process, long before there is full argumentation in court or detailed presentation of factual material. Substantive law is applied not at the end of a procedure that has been structured by lawyers and economists, as in the US, but throughout the development of the litigation. This means that the collection and organization of data is subject throughout the procedure to the judge's control. It is thus filtered through her eyes and her methods and shaped by her knowledge of principles and prior cases. In that context, she may often make factual determinations without providing opportunities for the parties to present fully developed analysis of the data.

These factors create a far more limited and constrained process for the application of economic methods to data than is found in US antitrust litigation. Whereas in the US system economists can analyse data subject only to the controls by the lawyers (and their clients) for whom they are working, they cannot operate this way in continental civil procedure. The judge is responsible for development of the factual material, not the lawyers and economists. There is thus far less freedom for economists to develop factual analysis and employ the tools of economic science.

As a result, there is also little opportunity to contest varying forms of economic analysis. Whereas in the US system economists for each side can analyse and contest the claims of opposing economists both during the dis-

covery phase of litigation and during the process of presenting the data to 
the judge, this type of contest is seldom, if ever, possible in continental courts. This lack of procedural opportunities for confrontations between opposing views may significantly reduce the value of economic analysis. Moreover, these diminished opportunities for contesting opposing views reduce incentives for thorough economic analysis that can push the interpretive limits of the available data.

The continental model of centralized procedural authority thus significantly constrains the operations of economists, and it may, as a consequence, reduce the value of economic science. Accordingly, reduced data access combines with reduced opportunities for the development of economic analysis in ways that may diminish the quality of the factual material presented.

\section{THE ROLE OF DATA INTERPRETATION}

The procedures of legal institutions and the decision-making methods within them transform raw data into legally relevant 'facts'. This process of transformation is usually referred to as the 'interpretation' of data. It involves assessing the relevance of data, sorting and categorizing data and generally relating specific elements of data together to form 'factual' narratives that form the basis for decision making. Economics can be of enormous importance in deepening, broadening and enriching this interpretive process - that is, in the 'transformation' of 'data' into legally approved and procedurally accepted 'facts'. Indeed, its primary value may be that it can generate a more insightful and sophisticated interpretation of data.

\subsection{US Antitrust: Relatively Free Rein for Economists}

In the US system, the judge plays only a limited role in this interpretive process. It is not her responsibility to acquire and assemble the data and piece together the construction of a credible narrative. These functions are the primary responsibility of the lawyers. They organize, sort and give meaning to the data. They then present their interpretations to the judge or jury for choices among the pre-formulated narrative items. Regardless of whether there is a judge or a jury, the decision maker is faced with choices presented by the lawyers, and her role is to choose among the elements of interpretation that have been provided by the parties. This difference between US and continental procedures is fundamental and often not adequately understood by outside observers.

One major consequence of this characteristic of US litigation is that economists in US antitrust litigation tend to be relatively unfettered in performing 
their interpretive functions by the constraints that often influence the process of factual interpretation in other systems. The economists and lawyers for each side are permitted to perform their interpretive functions with minimal need to conform to pre-established institutional influences and constraint. They are free to pursue particular interpretations that are structured neither by the concepts of the legal system nor by existing legal precedents.

\subsection{Europe: The Impact of the Judge's Roles and Incentives}

In continental court procedures, the factors that influence data interpretation differ in important ways from those typical in US antitrust litigation. In particular, the judge interprets economic data subject to constraints and influences that play little or no role in the interpretation of data in US federal courts. I mention here only some of those differences.

First, it is important to remember that data interpretation in continental European litigation procedure is done only by judges. This, by itself, distinguishes it from US procedure, where a jury may perform that function. Where there is a jury in the US, it alone is responsible for interpreting facts. ${ }^{31}$ Moreover, even where there is no jury, procedures are used that tend to place the judge in the role of the jury. This means, for example, that determinations of law and determinations of fact are strictly separated rather than temporally interspersed as is typical in the continental model.

Second, and unlike the US judge, the continental European judge is obligated to know the substantive law that is potentially applicable to the cases she is assigned to handle and to apply the substantive law continually to the procedural development of the case. The entire procedural structure centres on the professional expertise of the judge in both substantive and procedural law, and, as noted above, many features of the entire legal system are intended to maximize the judge's knowledge of substantive law and underscore its importance.

This means that the judge starts with often highly developed and specialized knowledge about the abstract principles to be applied in cases and about prior interpretations of similar data. She necessarily interprets the new data through the concepts, categories and prior cases that comprise that field of substantive law. These concepts and categories necessarily shape and guide her interpretation of that data. Moreover, the judge's interpretation of data through these categories takes shape not only after

31 There are special and rare cases in which, on request of a party, the judge may take responsibility for overriding a jury's determination of the facts. This may occur, for example, where the judge is convinced that the jury could not reasonably reach the conclusion that it has reached. 
the presentation of data by the parties, as in the US, but throughout the procedure, often before there has been opportunity for the parties' representatives to develop their own factual analysis. In some systems, party representatives have almost no role in interpreting data.

The consequences for the use of economics are striking. The role of economists in interpreting data is constrained to a very significant extent by the role of the judge in interpreting data. In sharp contrast to the US situation, where there are few procedural constraints on the opportunities for economists to develop their interpretations of the data, the economist in the continental context is far more constrained in performing her interpretive role. The judge's interpretations are driven by the categories and concepts of the substantive law and may be established and fixed early in the procedure - prior to any opportunity for economists to influence the interpretation. In contrast to the US practice of allowing the parties to use economics to develop interpretations of data and then seeing which ones can be substantiated under applicable legal norms, the continental practice works the other way round. The judge decides which provisions of the law, if any, need to be supported by economic analysis of the data. The cognitive impact of this difference can be profound.

\section{CONCLUDING COMMENTS}

This brief review illustrates the degree to which economics is embedded in the institutions and procedures of the competition-law system in which it is used. These institutions and procedures transform the abstract language and universalist posture of economics into a set of decisional influences that compete with other influences in generating specific decisions. The way economics functions in one institutional context may thus differ greatly from the way it operates in others, and it certainly operates very differently than it does within the economics community itself.

These institutional and procedural factors condition the use of economics in fundamental ways. They determine how much access economists have to data, what data is actually made available for economic analysis and in what quantities, what kinds of incentives there are for acquiring data, how the tools of economics can be employed, what incentives there are for their use and many other factors. In order to analyse the decisions that are likely to be made using economics in competition law, it is necessary to understand those factors. As we have seen, however, these influences are susceptible to systematic analysis.

Our application of this analysis to the relationship between US and EU competition laws demonstrates its potential value. Taking institutional 
embeddedness into account in relating US experience to decisions about the use of economics in competition law in Europe reveals dimensions of the issue that are critical for a full understanding of it. The factors that condition the role of economics in the US courts and those that operate in European courts often differ in fundamental ways. To the extent that the conditioning factors are similar, US experience can provide guidance for European decision makers, serve as a basis for predicting outcomes and, perhaps, support decisions there. To the extent that the conditioning factors are dissimilar, however, the potential value of referring to US experience with the use of economics may be diminished. At least it requires a more thorough and careful comparison of the differences.

Economics can play valuable roles in the development and application of competition law in Europe. It has in the past, and it will continue to do so in the future. It is indispensable for effective competition-law analysis. The institutional-embeddedness issues raised here do not detract from that value, but seek to enhance it by pointing to a more nuanced and presumably, therefore, more valuable view of how economics can be used, particularly in transnational contexts. 